\title{
Automatic docking of a small number of ligands into a large number of binding sites
}

\author{
Alexander Kos \\ From 8th German Conference on Chemoinformatics: 26 CIC-Workshop \\ Goslar, Germany. 11-13 November 2012
}

Very fast docking programs [1] enable new applications. In predefined workflows we start with an SDFile, filter the structures by substructure queries, followed by PASS predictions [2]. The remaining few structures are docked into 100 binding sites chosen for predicting adverse effects. The results are good indicators if a lead compound should be considered risky.

Published: 22 March 2013

\section{References}

1. Thomsen R, Christensen MH, MolDock : A New Technique for HighAccuracy Molecular Docking. J Med Chem 2006, 49:3315-3321.

2. Poroikov W, Filimonov DA, Yu V, Lagunin AA, Kos A: Robustness of biological activity spectra predicting by computer program PASS for non-congeneric sets of chemical compounds. J Chem Inform Comput Sci 2000, 40:1349-1355.

\section{doi:10.1186/1758-2946-5-S1-P5}

Cite this article as: Kos: Automatic docking of a small number of

ligands into a large number of binding sites. Journal of Cheminformatics

2013 5(Suppl 1):P5.

Publish with ChemistryCentral and every scientist can read your work free of charge

"Open access provides opportunities to our colleagues in other parts of the globe, by allowing anyone to view the content free of charge."

W. Jeffery Hurst, The Hershey Company.

- available free of charge to the entire scientific community

- peer reviewed and published immediately upon acceptance

- cited in PubMed and archived on PubMed Central

- yours - you keep the copyright

Submit your manuscript here:

http://www.chemistrycentral.com/manuscript/

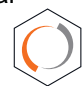

Chemistry Central 